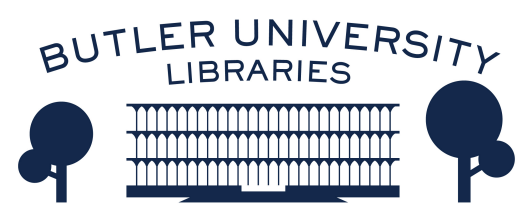

Journal of Hindu-Christian Studies

Volume 22

Article 8

January 2009

\title{
Ecstasy and Nonduality: On Comparing Varieties of Immanence
}

John J. Thatamanil

Follow this and additional works at: https://digitalcommons.butler.edu/jhcs

Part of the Religion Commons

\section{Recommended Citation}

Thatamanil, John J. (2009) "Ecstasy and Nonduality: On Comparing Varieties of Immanence," Journal of Hindu-Christian Studies: Vol. 22, Article 8.

Available at: https://doi.org/10.7825/2164-6279.1435

The Journal of Hindu-Christian Studies is a publication of the Society for Hindu-Christian Studies. The digital version is made available by Digital Commons @ Butler University. For questions about the Journal or the Society, please contact cbauman@butler.edu. For more information about Digital Commons @ Butler University, please contact digitalscholarship@butler.edu. 


\title{
Ecstasy and Nonduality: On Comparing Varieties of Immanence
}

\author{
John J. Thatamanil \\ Vanderbilt University Divinity School
}

\section{Immanence and Scripture}

FOR the benefit of those who have not read my book, let me offer a few framing remarks. I begin by noting that my initial working title for the book was Ecstasy and Nonduality, not The Immanent Divine. Although somewhat technical, the earlier title had the virtue of stipulating that my book compares two specific types of divine immanence. I root each sort of immanence in a fundamental scriptural locus within the Christian and Hindu traditions. In the Christian case, the scriptural text is Romans 8:26, "Likewise the Spirit helps us in our weakness; for we do not know how to pray as we ought, but that very Spirit intercedes with sighs too deep for words" (NRSV). The King James Version reads, "Likewise the Spirit also helpeth our infirmities: for we know not what we should pray for as we ought: but the Spirit itself maketh intercession for us with groanings which cannot be uttered." In the Hindu case, the scriptural text is the Upanishadic mahavakya, "Aham Brahmasmi" from Brhadaranyaka Upanishad 1.4.10. In this Christian scripture, divine immanence is experienced as an ecstatic event accomplished by the work of the Holy Spirit that grasps and prays through us when we know not how to pray. In the Hindu scripture, immanence is given by way of nonduality: one just is Brahman.

Rather than examining and comparing these verses directly, I turned to two theologians whose entire corpus can be read as extended commentary on these verses. In the Christian case, I chose Paul Tillich and in the Hindu case, Sankara. So, contrary to McLaughlin's contention that the book begins with and adheres to some vaguely Spinozistic or Deleuzian notion of immanence rather than begin by way of scripture, this book is about just these two modes of healing immanence as understood by way of theological reflection on key scriptural loci. My book also concludes by suggesting that Tillich's fondness for Romans 8:26 can be enriched by a fuller attention to Galatians 2:20 where Paul writes, "And it is no longer I who live, but it is Christ who lives in me." This more stable and enduring kind of immanence bespeaks a strong doctrine of sanctification, one that remains insufficiently developed in Tillich's own theology but might be possible for Tillichians after a more thorough encounter with Sankara's nondualism.

The compelling and challenging question that might be put to my book is whether I have selected the right Hindu conversation partner.

John J. Thatamanil is Assistant Professor of Theology at Vanderbilt Divinity School. His areas of expertise include theologies of religious pluralism, comparative theology, the theology of Paul Tillich, HinduChristian Dialogue and Buddhist-Christian Dialogue. He teaches courses in all of the above mentioned areas as well as courses in process thought and philosophical theology. He is currently completing a book provisionally entitled, Religious Diversity After Religion: Rethinking Theologies of Religious Pluralism (under contract with Fordham University Press). Thereafter; he plans to turn to a book on the I-Sayings of Jesus in the Gospel of John and the homologous I-Sayings of Krishna in the Bhagavad Gita. That book is entitled, No One Comes to the Father but by Me? The Gospel of John and the Challenge of Religious Diversity (Westminster John Knox Press). Thatamanil is also Chair of the AAR's Theological Education Steering Committee and the Project Director for the AAR/Luce Summer Seminars in Theologies of Religious Pluralism and Comparative Theology. 
After all, there is no shortage of ecstatic immanence in Hindu traditions. I am thinking in particular of the Tamil poet-saint Nammalvar and by extension of the Sri Vaisnava tradition for whom he is central. Nammalvar believes that his own poetry is itself the Lord's singing through him. ${ }^{1}$ Here we find what appears to be a profound homology to the Pauline notion of the Spirit that prays in us. The challenge to be posed to a work like mine is not that it has embraced some generic extrascriptural notion of immanence but that it has not engaged the right sort of immanence. To such a hypothetical challenge, I respond as follows: we need a wide variety of comparative projects in order to understand better the relationship between Hindu and Christian traditions and thinkers. I welcome such additional projects and would argue that there is no such thing as a "natural" comparison. I venture a comparison of Tillich and Sankara precisely because Sankara's nondualism is a more difficult and demanding challenge to Christian habits of mind whereas Sri Vaisnava traditions and the theology of Ramanuja are likely to seem more familiar. Moreover, both Tillich and Sankara, although they appeal to different types of immanence, share a deep commitment to the notion that ultimate reality is not a being among beings and is moreover transpersonal. ${ }^{2}$ That said, a three way exchange between Tillich, Sankara and Ramanuja is very much needed if we are to clarify ongoing conversations on the relationship between God and the world especially those that go by the name of panentheism.

\section{The Question of Orientalism}

Writing comparative theology is a complex matter fraught with a great many dangers. The sins of $19^{\text {th }}$ century predecessors who went by the name "comparative theologian" inevitably weigh upon the mind. In my case, writing as I am about Sankara and Tillich, a preoccupation with Rudolf Otto was inevitable. I am thinking in particular of his important work Mysticism East and West which offered a full-scale comparison of Eckhart and Sankara. ${ }^{3}$ Tillich's indebtedness to Eckhart makes this comparison an especially sensitive matter. Those who have taken the time to read Otto's book carefully will know that it is a sophisticated and careful work, one that gets Sankara right in multiple ways, most especially in Otto's appreciation of the often overlooked theistic dimensions of Sankara's thought. Nonetheless, his work has rightly come in for criticism for drawing a sharp and asymmetrical dichotomy between East and West, between a passive and ethically deficient Eastern mysticism and a dynamic and worldaffirming Western mysticism. On every relevant point of comparison, Eckhart's mysticism is shown to be superior to Sankara's mysticism. In a post-Saidian, postcolonial world to replay such dichotomous dualisms would amount to an unpardonable sin. I wrote my book with a hypersensitivity to that issue and strove assiduously to avoid that sin. Whether I erred by remaining so focused on avoiding that particular error and thereby fell prey to a whole host of others is a question that I must largely (though not wholly) leave for my readers.

It, therefore, gave me no small pause to see that Michelle Voss Robert's response begins with just these considerations. Thankfully and to my immense relief, Roberts judges that I have not fallen prey to the sin of the old orientalism. Her worry is rather different, and in truth, equally as frightening - all the more so because it is a sin that I had not considered. She poses the question shrewdly and with remarkable skill. Writing about Rambachan's and my worldaffirming Advaita, she writes "Are these dynamic, active, worldly non-dualisms new vindications of an essentially 'Christian' way of thinking? Do Christianity and the West still win out in the end? Is it all just a 'logic of the same' in which Advaita Vedanta now mirrors the West positively instead of serving as its photographic negative-in other words, does Advaita now gain credibility because it so closely resembles what the West values?" I consider this a genuinely probing and important question. Thankfully, Roberts has exonerated both Rambachan and me from this charge, and for that I am both grateful and relieved. For my part, I would point only to the way in which Rambachan and I generate our more worldaffirming reading of Sankara. First, both of us explicitly recognize that Sankara had little patience for subjective idealism of the sort that he found in Buddhist Yogacara. Sankara 
explicitly rejected the idea that the world was merely a projection of mind just as he rejected the idea that there is no fundamental difference between the waking state and the dream state. Secondly, Rambachan makes an additional appeal to key Upanishadic texts to justify a more world-affirming reading of Advaita. These are but two of many examples that demonstrate that a world-affirming reading of Advaita is not derived by appeal to extrinsic Christian sources or norms. As Roberts rightly notes, the very charge that a world-affirming Advaita can only be generated by readers motivated by Christian concerns is to suggest that only Christians and the West are capable of world-affirmative reflection. Orientalism indeed! That said, Roberts is right to urge us to proceed further by developing the resources of a world-affirming Advaita for a variety of ends including ecological ethics.

\section{Learning from Sankara: On Apophatic Anthropology and the Status of Avidya}

At this juncture, I would like to note that my own overriding theological concern is whether Christian theology might more closely mirror Advaita rather than the other way around. The charge that would genuinely count against my project is one that contends that despite offering another more or less careful reading of Advaita, I have learned nothing from it, that my Christian theology continues on its course very much as it would have prior to encounter with Sankara. That charge strikes me as more serious because I believe that we are most likely to avoid old orientalisms just to the extent that we learn with and from persons of other traditions and are transformed by that learning.

For the sake of brevity, let me enumerate just two of the principle lessons that I have learned from Sankara. First, affirming nonduality does not amount to eviscerating transcendence. Put simply, the Advaita affirmation that the true self (atman) just is Brahman, the ultimate world ground, is not to know what Brahman is. As Rambachan and I both show, Sankara is absolutely relentless in affirming that even the most cherished terms in the Advaita vocabulary-self (atman), consciousness (cit), and being (sat)-are not ultimate and must finally be surpassed. The resulting position might well be called an "apophatic anthropology," one in which the true self remains necessarily a mystery to itself. The old Delphic and Socratic imperative, "Know Thyself" is accomplished, most paradoxically, when we realize that we cannot in fact know what we most truly are. Sankara's Advaita generates the most radical coincidence between immanence and what $I$ am calling a noetic transcendence rather than a spatialized transcendence. Contrary to the possible apprehension that nonduality eviscerates transcendence, I show that Advaita excludes only a spatialized transcendence. True, a visual metaphor that imagines Brahman as being elsewhere and above the world simply makes no sense from within Sankara's frame as my very being just is Brahman. But having said that, Sankara compels me to add that Brahman remains that from which all words and cognitions must fall away. Brahman is an excessive mystery to which language and thought is necessarily inadequate.

The second major lesson I draw from Sankara is that one can generate a profound and sobering account of the human predicament without rooting it in a fundamental ontological fault or rupture. Sankara presents a devastating picture of human life as marked by craving (raga) and aversion (dvesa), by grief (soka) and delusion (moha), which are in turn rooted in fundamental ignorance (avidya). Nonetheless, Sankara also consistently refuses to theorize avidya. If samsara as marked by craving, aversion, grief, and delusion is Sankara's diagnosis of the human predicament and if avidya is Sankara's etiological explanation for how we come to be in this predicament, Sankara refuses to make the further move of asking about the very condition for the possibility of ignorance. He does not ask, "Why avidya?," because to take the question seriously would result in dualism. If avidya is taken to be realand those who believe that avidya must be explained necessarily assume that it is ontologically real-then there would be a second reality over against Brahman and Advaita would be negated. As Daniel Ingalls has shown, for Sankara ignorance is a practical, pedagogical, and even soteriological problem 
that needs to be addressed and treated but not theorized. $^{4}$

\section{The Problem of Evil}

And this question about the status of ignorance brings me to McLaughlin's challenge that my position, derived from Sankara, risks trivializing evil and underplays the reality of the tragic. McLaughlin suggests that in my commitment to keep with Sankara's strong account of divine immanence, I willfully ignore the brutalities of human history and wish away the tragic complexities of human experience, even or perhaps especially that of would be saints. But, as I have already shown, I explicitly commend both Sankara and Tillich for their strong and compelling diagnoses of the human predicament. Indeed, I explicitly critique Vivekananda's polemic against Christianity famously epitomized in his fiery proclamation, "It is a $\sin$ to call men sinners." Vivekananda hopes to counter abusive treatments of Hindu traditions by contending that Hinduism, unlike Christian faith, affirms the dignity of the human soul by refusing to call human beings sinners. But Vivekananda's assertion fails to register much in Sankara's Advaita. While the term sin is absent, I spend many pages demonstrating that Sankara offers a devastating account of the human predicament and afflictions (klesa) that compromise human life. I do so explicitly to undo Vivekananda's occidentalism which is itself an aggressive inversion of orientalism. I dwell on this point because I am convinced that sensitive and nuanced comparative theology cannot get underway if comparativists do not break out of such polemical loops.

What I leave behind in Tillich is not his bleak diagnosis of the human predicament but rather his limited prognosis and even more so the ontology that renders such a prognosis inevitable. Sankara's Advaita by contrast demonstrates that there need be no necessary connection between a grave diagnosis of the human predicament and a limited prognosis of the same. Just as a patient might simultaneously hear both that he has cancer and that the cancer is entirely curable, it is possible to generate an acute account of the human predicament and yet to affirm a robust hope for comprehensive healing. ${ }^{6}$ What I reject in Tillich is his near claim that human fallenness is ontologically necessary and his explicit claim that fallenness is ontologically unavoidable. For Tillich, creatures can only be free if they stand outside the divine life, but just because they stand outside the divine life, their fallenness is unavoidable. Freedom comes with a very steep price as it perpetually threatens anything like a progressive movement into sanctification. In contrast to Tillich, I explicitly join Sankara in affirming that human beings can be both free and "fallen". without positing a fundamental dualism or distance between self and divinity. One can be Brahman and yet also be caught up in suffering of the human predicament. No attempt is made to explain just how this is possible. The task at hand is not to offer an explanation but rather to bring about liberation. ${ }^{7}$

My own primary motives are soteriological: I refuse to posit a fundamental rupture between God and humanity in order to allow for richer prospects for spiritual perfection, understood as sanctification in Christian traditions and living liberation (jivanmukti) in Sankara. Against Tillich's Lutheranism which offers relatively limited expectations for sanctification and is entirely lacking in any account of spiritual discipline - the latter always come under suspicion of works righteousness-I stand with both Wesley and Sankara in their sense that human beings are capable of experiencing deep and healing transformation. It is true that Sankara is absolutely relentless in affirming that liberation cannot be generated by action; Tillich would concur. But unlike Tillich, Sankara offers an account of karma yoga as a preparatory spiritual discipline that can make room for liberating knowledge. Moreover, once such liberating knowledge takes hold, the liberated person (jivanimukta) can live a life that is beyond bondage to afflictions and faults and in so doing live out a life of spontaneous compassion. Such a person is no longer obligated to follow ethical norms of dharma. In that sense, the jivanmukta is to use the Pauline phrase beyond the law.

This trajectory of thought should suffice to counter or at least to soften McLaughlin's charge that I offer no account of spiritual transformation. Perhaps I do not go far enough, but I surely argue that resources for such an 
account of spiritual discipline can be found in Sankara's thought especially in his Gitabhasya. Since McLaughlin has explicitly raised the question of whether the vision I articulate can offer robust possibilities for self-sacrifice and even martyrdom, let me add here that I believe that we have grounds for believing that human beings are capable of radical spiritual disciplines such as those of nonviolent resistance-ahimsa expressed as satyagraha-just to the extent that human beings possess, or are endowed by participation in the divine life, with the capacity for radical non-egocentric compassion even when confronted by the most vicious and brutal forms of human evil.

McLaughlin believes that I can generate my optimistic account of human spiritual capacities only by downplaying any serious account of the human predicament. He finds this inadequacy expressed in my vague categories of estrangement and self-enclosed finitude which sound far less dire and depressing than traditional Christian talk about sin and guilt. I believe that McLaughlin has overlookedperhaps I underemphasized the point-that I appeal to a more abstract terminology, in part, because I believe that configurations of sin and alienation are deeply local. Tillich himself noted that Christian understandings of the human predicament have shifted markedly over the course of western history. For the early Church, the human predicament was experienced as bondage to the powers of $\sin$, death, and the devil. In the medieval period, the human predicament was experienced in terms of guilt and debt, a debt that must be paid to the Divine. Against these culturally contingent configurations of sin, Tillich argued that sin or estrangement in his own time had to be reconfigured in terms of meaninglessness.

The more abstracted or "vague" account of sin as estrangement or self-enclosed finitude is, at least in part, my attempt to recognize that the human predicament can take on a variety of local configurations in different historical and cultural milieus. My goal is not to downplay these particular configurations of estrangement but rather to be cautious about imposing some particular theological anthropology or some particular account of the human predicament as universal and then writing such accounts into one's ontology. I am thinking here of forms of missionary malpractice that have insisted that only Christian tradition has the cure for the disease of sin and guilt while ignoring that other traditions do not diagnose or experience the human predicament in these terms. Such missionizing ends up selling not just the Christian cure but also as it happens the Christian disease, a disease that the missionized did not even know they had!

In sum, from Tillich I have learned to be attentive to the variety of ways in which the human predicament is configured and from Sankara, I have learned not to ontologize any such account as implying a tragic rupture between human beings and divinity. My sense is that McLaughlin has overestimated my indebtedness to Neville who takes up no more than 20 pages of my book and has underestimated my indebtedness to both Tillich and most especially to Sankara.

More fundamentally, McLaughlin's most profound worries about my project surface at just those moments when I try to reconfigure Christian theology by appeal to Sankara. At just these moments, we hear predictable worries about syncretism, about the melding of religious traditions. The constraints of space will not permit me to offer an extended response to these and other noteworthy objections that McLaughlin advances concerning agency, heroic self-sacrifice, and the nature of spiritual disciplines.

I conclude by asserting that if comparative theology fails to learn from and be transformed by interreligious encounter, it will surely fall prey to the errors of the Christian colonial past, the errors that Roberts so well enumerates. The other will remain not only other, but an other to be refuted, chastened, or converted possessing at most "a ray of that truth" found in the fullness of Christian tradition. McLaughlin's appeal to Nostra Aetate suggests that he remains unwilling to move beyond the version of inclusivism articulated in that Vatican II document. This refusal leaves us with the impression that Christians have nothing at all to learn from what others have come to know about God by way of their own deep traditions. But if in fact Christians have little to learn, and if moreover, any such learning amounts to a syncretism that 
brings with it the threat of identity loss, then why venture into comparative theology at all? An older style of apologetics would suffice.

\section{Notes}

1 "My lord/who swept me away forever/into joy that day,/made me over into himself/and sang in Tamil/his own sweet songs/through me...." Nammalvar, Hymns for the Drowning: Poems for Visnu by Nammalvar, trans. A.K. Ramanujan (New York: Penguin Books, 1993) 85.

${ }^{2}$ By now, the notion that Tillich or Sankara holds to an impersonal or nonpersonal conception of divinity has largely been discredited in the relevant scholarly communities. However, the notion that ultimate reality cannot be characterized as either a person or as a being among beings does mean that in some sense ultimate reality exceeds the personal. Hence, my term "transpersonal."

3 Rudolf Otto, Mysticism East and West: A Comparative Analysis of the Nature of Mysticism, trans. Bertha L. Bracey (1932; reprint, Wheaton, Ill: The Theosophical Publishing House, 1987).

${ }^{4}$ Daniel H. H. Ingalls, "Sankara on the Question:

Whose is Avidya?' Philosophy East and West 3:1 (1953) 69-72.

${ }^{5}$ Vivekananda, "Chicago Addresses," The Yogas and Other Works, ed. Swami Nikhilananda (New York: Ramakrishna-Vivekananda Center, 1953), 188.

${ }^{6}$ Indeed, one might well wonder if any tradition can endure if it either trivializes the gravity of the human predicament as experienced and suffered or fails to offer a deep and lasting hope for treating that predicament. Might it be a cross-cultural criterion for assessing the adequacy of a religious vision that it must accomplish both tasks well?

${ }^{7}$ Although space constraints prevent the possibility of venturing a full scale argument, I believe that Sankara's refusal to provide an ontology of avidya has intriguing resonances with a long Neoplatonic and Christian theological trajectory that treats evil as privation and insists that it has no positive reality or being. As noted earlier, it is precisely because Sankara does not want to give avidya any ontological status that he refuses to give a theoretical account of avidya and its origins. 